Journal of Innovative Engineering
and Natural Science

\title{
Eklemeli imalat yöntemlerinde metal tozu patlama riski ve önleme yöntemleri
}

\author{
Seda Ataş Bakdemir ${ }^{\mathrm{a}, \mathrm{b}}$, (D) Yahya Bozkurt ${ }^{\mathrm{c}}$ ve (D) Serdar Salman ${ }^{\mathrm{c}, \mathrm{d}}$
}

${ }^{a}$ Milli Savunma Üniversitesi, Deniz Harp Okulu, Makine Mühendisliği, Tuzla, İstanbul ve 34940, Türkiye.

${ }^{b}$ Marmara Üniversitesi, Fen Bilimleri Enstitüsü, Metalurji ve Malzeme Mühendisliği, Kadıköy, İstanbul, 34722, Türkiye.

'Marmara Üniversitesi, Teknoloji Fakültesi, Metalurji ve Malzeme Mühendisliği, Kadıköy, İstanbul, 34722, Türkiye.

${ }^{d}$ Milli Savunma Üniversitesi, Beşiktaş, İstanbul, 34722, Türkiye.

\section{MAKELE BİLGİSI}

\section{Makale Geçmişi:}

Geliş 22 Haziran 2021

Düzeltme 7 Temmuz 2021

Kabul 29 Temmuz 2021

Çevrimiçi mevcut

Anahtar Kelimeler:

Toz patlamas 1

Metal toz bulutu

Eklemeli imalat

Patlama güvenliği

\section{ÖZET}

Metal tozu patlamaları, çeşitli yanıcı malzemelerin tozlarını üreten, kullanan ve/veya işleyen endüstrilerde güvenlik açısından kritik bir tehdit oluşturmaktadır. Toz patlamaları ne yazık ki genellikle ciddi yaralanmalara, can kayıplarına ve maddi hasara neden olur. Metal tozları, yanma reaksiyonları sonucu oluşan yüksek sıcaklık dereceleri, daha ışınımsal ısı transfer etkileri ve su ile yüksek derecedeki reaktif etkileşimleri nedeniyle artan bir patlama şiddeti ve hassasiyeti sergilemektedirler. Endüstriyel tesislerde gerçek ortam koşullarındaki patlama gelişimini tahmin edecek yöntemlerini geliştirmek karmaşık ve zordur. Bir metal toz türü için, toz bulutlarının tutuşma olasılığı ve yanma oranları, toz bilimi ve teknolojisinde belirtilen parametreler ile önemli ölçüde değişmektedir. En tehlikeli süreçler, tutuşmaya en duyarlı ve reaktif olan daha küçük parçacıkları içermektedir.

Avantajlarıyla dikkat çeken eklemeli imalat yöntemleri, çeşitli ilkeler ve hammaddeler kullanan tasarımlar ile daha geniş kullanım alanları bulmaktadır. Ancak bu teknoloji, benzersiz bir üretim potansiyelinin yanı sıra toz patlama riskini de beraberinde getirmektedir. Bu çalışmada, bir toz patlaması için gerekli olan koşullar, 1Sı kaynakları açıklanmış ve toz özelliklerinin patlama üzerindeki etkileri tartışıldıktan sonra eklemeli imalat yöntemlerinde artan metal tozu kullanımı ile patlama risk ilişkisi analiz edilmiş ve alınabilecek koruyucu önlemler ile bu önlemlerin metal tozu içeren süreçlerdeki uygulama zorlukları üzerinde durulmuştur.

2021 JIENS Tüm hakları saklıdır.

\section{Metal dust explosion risk in additive manufacturing and prevention methods}

\section{ARTICLE INFO}

\section{Article history:}

Received 22 June 2021

Received in revised form 07 July 2021

Accepted 29 July 2021

Available online

Keywords:

Dust explosion

Metal dust cloud

Additive manufacturing

Explosion safety

\begin{abstract}
Metal dust explosions pose a critical safety threat in industries that produce, use and/or process dusts of various combustible materials. Unfortunately, dust explosions often cause serious injury, death and financial loss. Metal powders exhibit increased explosion severity and sensitivity because of their large heats of combustion, higher combustion temperatures, radiative heat transfer effects, and highly reactive interactions with water. Developing methods to predict explosion progression in real ambient conditions in industrial plants is complex and difficult. For a metal powder type, the ignition probability and combustion rates of dust clouds differ considerably with the parameters specified in powder science and technology. The most dangerous processes involve the smaller particles that are most sensitive and reactive to ignition.

Additive manufacturing methods, which attract attention with their advantages, are commonly used with designs using various principles and raw materials. However, this technology brings with it a unique production potential as well as the risk of dust explosion. In this study, the fundamental requirements for an explosion, heat sources are explained and after discussing the effects of dust properties on the explosion, the relationship between the increased use of metal powder in additive manufacturing methods and the explosion risk is analysed. In addition, the protective measures to be taken against the risk of metal dust explosion and the difficulties of applying these measures are emphasized. 2021 JIENS All rights reserved.
\end{abstract}




\section{GíRiş}

Toz parçacıkları, çapı genellikle 1 mm'den küçük, hava ortamında asılı kalabilen ve şartlara bağlı olarak çökebilen, birimsel olarak belirli bir hacim içerisindeki ağırlıklarına $\left(\mathrm{m}^{3} / \mathrm{mg}\right)$ veya toz sayısına $\left(\mathrm{m}^{3} / \mathrm{tane}\right)$ bağlı olarak ifade edilen parçacıklardır [1]. Partiküllerin alt grubunu oluşturan toz tanelerinin boyutları 0.10-300 $\mu \mathrm{m}$ arasında değişmektedir. Tozların havada asılı kalıp kalmama davranışları ise çap, büyüklük, şekil, yoğunluk vb. aerodinamik özelliklerine bağlı olarak değişmektedir [2].

Genel olarak, organik maddelerin çoğu, birçok metal ve bazı metal olmayan inorganik maddeler; belirli bir parçacık boyutu değerlerinde küçük olduklarında ve havada yeterli konsantrasyonu oluşturacak şekilde dağılım sergileyip asılı olarak kalabildikleri koşullarda yangın veya patlama meydana getirebilmektedir [3]. Toz patlaması olarak adlandırılan olgu temel yanma prensiplerine dayanan ve günlük hayatta kolayca gerçekleşebilecek bir olaydır. En basit olarak bir odun parçasının tutuşturulduktan sonra yavaş bir yanma gerçekleştirerek belirli bir zaman diliminden sonra $1 s ı$ enerjisini serbest bıraktığını görebiliriz. Ancak odun parçası daha küçük parçalar haline getirildiğinde, havayla temas eden yüzey alanın artmasına bağlı olarak yanma hızı da artar. Odun parçası boyutları maksimum $0.1 \mathrm{~mm}$ boyutunda olan daha küçük partiküller haline getirildiğinde ise bu parçacıklar havada yoğun bir bulut halinde yayılır. Bu partiküller oluşan bulut bir ısı kaynağı ile karşılaştığında yangın veya yeterli basınç sağlandığında patlama ile sonuçlanabilir. Bu durum bir toz patlamasını ifade etmektedir [4,5]. Yangın ve patlama arasındaki en temel fark ise enerji salınım hızlarıdır. Yangında enerji salınımları uzun sürelerde gerçekleşirken patlamalar için bu süre çok kısa ve anidir. Patlama için bir yangın oluşumu ve kimyasal tepkimenin gerçekleşmesi gerekmeyebilir. Ancak yangın bir patlama için öncü olabilirken, aynı şekilde patlama da bir yangına öncülük edebilir, ortamda diğer yanıcı gaz ve sıvıların bulunması ise ikincil patlamalara sebebiyet verebilmektedir [6].

Metal sektörü dünyada olduğu gibi Türkiye içinde önemli bir sektör kolunu temsil etmektedir. Her ne kadar uzman olmayan kişilerin ortak deneyimi, metallerin tipik olarak yanmayacağı yönünde olmasına rağmen birçok metal, ince bir toz olarak bulunduğunda yangın ve patlama tehlikesi oluşturmaktadır. Ulusal Yangından Korunma Birliği (NFPA)'nın Yanıcı Metaller Standart'ına (NFPA 484) göre, "yeterince ince formdaki metal yanıcı ve/veya patlayıcı olabilir" şeklinde ifadesi vardır. Buna iyi bir örnek, oksitlenmemiş ince bir toz olarak bulunduğunda demir tozunun yanıcılığıdır $[7,8]$.

Son yıllarda artan rekabet koşulları ve üretim hızı, metal arıtma, işleme ve depolamadaki büyüme, metal tozu patlamaları kazalarının oluşmasına yol açmıştır. 2010 yılında, New Cumberland, WV'de bir metal üreticisi olan AL Solutions şirketinde arızalı bir karıştıııcıda sürtünmeli ssıtma veya kıvılcımlar tarafından tetiklenen yıkıcı bir metal tozu patlaması yaşanmıştır. Bu titanyum ve zirkonyum tozu patlaması üç kişinin ölümüne ve bir ciddi yaralanmalara yol açmıştır [9,10]. Ağustos 2014'te Çin'in doğu Jiangsu Eyaletinde General Motors'a parça sağlayan bir fabrikada çok daha yıkıcı bir başka metal tozu patlaması meydana gelmiştir. Yetersiz tesis bakımı ve yetersiz izolasyon teknikleri, alüminyum alaşımı tozunun tehlikeli bir şekilde birikmesine ve yeterli bir tutuşma kaynağı bulması ile patlamasına sebep olmuştur. Bu patlamanın ise 146 kişinin ölmesi ve 114 kişinin yaralanmasıyla sonuçlanması, toz patlamasından kaynaklanan kazaları önlemek için daha etkili yöntemler ve maddeler geliştirme ihtiyacına yol açmıştır [10,11].

Bu çalışma kapsamında ciddi bir sağlık, çevre ve güvenlik problemi oluşturabilecek metal tozu patlamalarının oluşum sebepleri ve kaynaklarının belirlenmesi, önlemek için uygulanması gereken tedbirler açıklanacaktır. 
Ayrıca özellikle son yıllarda popüler hale gelen toz metalürjisi (TM) ve eklemeli imalat teknikleriyle (EI) birlikte artan metal tozu kullanımında dikkat edilmesi gereken hususların incelenmesi hedeflenmektedir.

\section{TOZ PATLAMASI}

\subsection{Toz Patlamasının Oluşması İçin Gerekli Şartlar}

Bir oksitleyicinin varlığı ile meydana gelen yanmada ayrıştırılan yakıta bağlı olarak çeşitli ürünler açığa çıkmaktadır. Oksidatif reaksiyonlar sırasında organik hidrokarbon ayrışması genellikle karbondioksit, su buharı ve 1sı yayar. Organik maddelerin aksine, metal yanması, oluşan ürünlerde çok daha fazla değişkenliğe sahiptir. Oksijen altında tutuşmanın ardından, saf metal tozları tipik olarak ısı ve ilgili metal oksit oluşturmak için ayrışır. Yakıt cinsi ne olursa olsun patlama olması için sağlanması gereken ve yanma beşgeni olarak isimlendirilen evrensel kriterler söz konusudur (Şekil 1'de gösterilmiştir.). Bunlar:

(1) yanıcı tozun varlı̆̆

(2) oksitleyici (havada O2),

(3) tozun havadaki konsantrasyonu,

(4) yeterli ateşleme kaynağ1,

(5) kapalı ortam olarak sayılabilir [10].

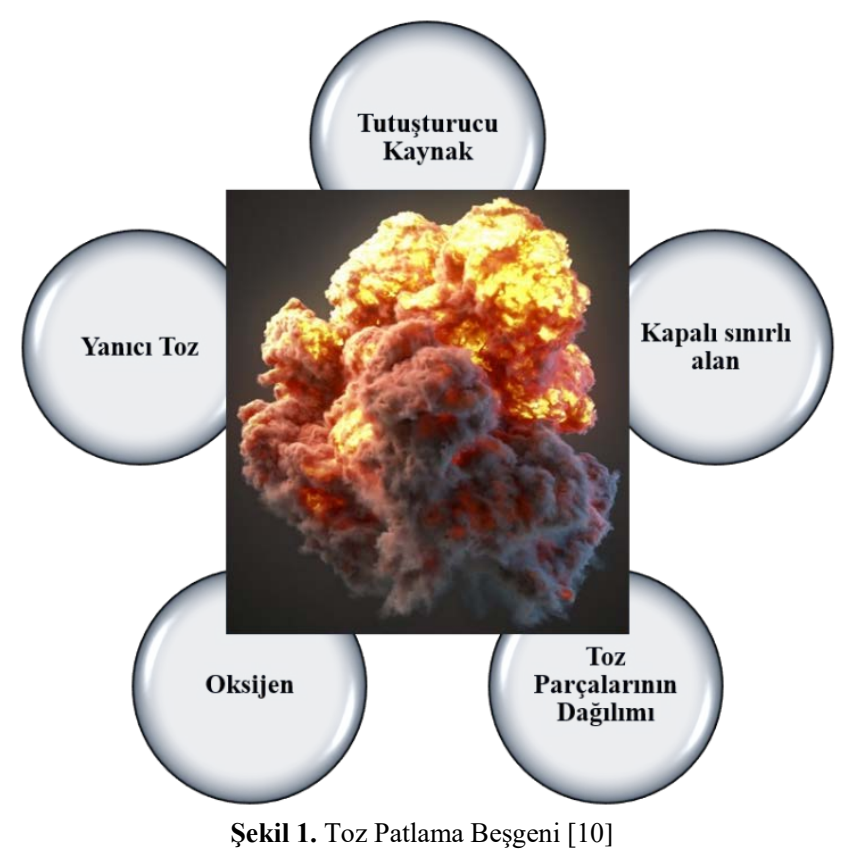

Havadaki oksijen, çoğu yanıcı madde için en yaygın oksitleyicidir. Bununla birlikte, materyali oksitleyebilen diğer gazlar da yanıcı bir toz olayında bir oksitleyici görevi görebilir. Örneğin bazı metaller, diğer yakıtlar için söndürme ajanı olarak kullanılan halojenler ile, hatta karbondioksitle reaksiyona girebilmektedir. Malzemeye bağlı olarak, yanıcı bir toz olayını tutuşturmak için statik elektrik, elektrikli ekipmandan gelen kıvılcımlar, sıcak yüzeyler, sürtünmeli ısıtma ve açık alevler gibi çeşitli tutuşma kaynaklarından oluşmaktadır. Tozlar katı fazda olduğundan 
tutuşabilmesi için tozun oksitleyici bir ortamda uygun konsantrasyonlarda dağıtılması gerekmektedir. Toz, toz işleme süreçleri veya ekipmandan istem dışı salınımlar veya bir tesisteki birikimlerin dağılmasıyla dağılabilir. Yüksek derecede basınca neden olan hasarlı bir patlamanın oluşması için sıcak yanma ürünlerinin genişlemesini sınırlayarak bir basınç artışına neden olacak şekilde bir miktar hapsetme gereklidir. Hapsedilme ise bir toz toplayıcı veya bir binanın duvarları gibi ekipmanın dış kabuğundan veya çok sıkışık bir alanın varlığından kaynaklanabilir [12].

\subsection{Tozların Sinıflandırılması}

Bir toz tabakası, yabancı bir kaynakla tutuşturulabiliyorsa ve bu şekilde oluşan yangın, dış kaynak uzaklaştırıldıktan sonra yeterince yayılıyorsa "yanıcı" olarak kabul edilir. Tüm patlayıcı tozlar yanıcı özellikte olmalıdır, ancak tüm yanıcı tozlar kolayca patlayıcı değildir [13,14]. Örneğin, antrasit ve grafit, yüksek yanma sıcaklıklarına sahip olmalarına rağmen kolay patlayıcı değildir. Bir toz tabakasının tutuşabilirliğinin ve bir toz tabakasının yanma yoğunluğunun bir başka ölçüsü "yanma sınıfı"dır. Uluslararası Sosyal Güvenlik Derneği (ISSA) standardı dikkate alınarak yapılan bu sınıflandırma, bir gaz alevi veya sıcak platin tele maruz kaldığında tanımlanmış bir yığının yanma davranışını esas almaktadır.

(1) CC1: ateşleme yok; kendi kendine yanma yok.

(2) CC2: kısa ateşleme ve hızlı söndürme; kısa süreli yerel yanma.

(3) CC3: bölgesel yanma veya yayılmadan parlama; yerel sürekli yanma, ancak yayılma yok.

(4) CC4: parlayan bir yangının yayılması; yayılma için için yanan yanma.

(5) CC5: açık ateşin yayılması; açık alev yaymak.

(6) CC6: patlayabilir yanma; patlayıc yanma.

Metal tozları yanma tehlikesi oluşturabilme ihtimalleri açısından çeşitli sınıflara ayrılmaktadır. Bunlar reaktif (demir, çelik, çinko vb.), oldukça reaktif (silikon vb.) veya aşırı derecede reaktif (alüminyum ve magnezyum vb.) olarak sayılabilir. Her reaktiflik derecelerine karşılık gelen tehlike sınıfı bulunmaktadır. Bu sınıflandırılmaların belirlenmesinde laboratuvar ortamında ölçülen ve toz patlamasının ciddiyetini ifade eden $\mathrm{K}_{\mathrm{St}}$ değeri ve maksimum yanma basıncı $\left(\mathrm{P}_{\max }\right)$ değeri dikkate alınır. Küp kök yasası olarak dayandırılan ve Bartknecht tarafından tanımlanan "K $\mathrm{K}_{\mathrm{St}}$ değeri" terimi, bir toz tutuşturulduğunda $1 \mathrm{~m}^{3}$ tanktaki maksimum basınç artış oranını diğer bir deyişle "toz patlaması şiddeti" temsil etmektedir. "St" kısaltmasının kökeni, toz anlamına gelen Almanca "staub" kelimesinden gelmektedir.

Patlama endeksleri testi EN 14034-1: 2004 (toz bulutlarının maksimum patlama basıncının Pmax'ın belirlenmesi) ve EN 14034-2: 2006 (toz bulutlarının maksimum patlama basıncı artış hızının belirlenmesi $\mathrm{K}_{\mathrm{St}}$ ) standartlarına uygun olarak yapılmalıdır [16]. Testler, en zorlu şartlardaki proses tesisi koşullarını simüle etmek için yüksek türbülans durumunu yeniden üreten 20 litrelik bir küre aparatında gerçekleştirilir ve maksimum patlama basıncı artış hızı Eş.1'de belirtilen şekilde hesaplanır.

$$
K_{S t}=\left(\frac{d P}{d t}\right) \max \times V^{1 / 3}
$$

Burada V test odasının hacmini $\left(\mathrm{m}^{3}\right)$ ifade etmektedir. Bu ilişki genellikle kübik yasa olarak adlandırılır. 1 bar ve oda sıcaklığı başlangıç koşulları ile $1 \mathrm{~m}^{3}$ küreye oranlanmış maksimum basınç artış hızını esas almaktadır. $\mathrm{K}_{\mathrm{St}}$ 
endeksinin geçerliliği test düzeneğinde kullanılan oda hacmindeki patlamalar için geçerli olmaktadır. Çünkü laboratuvar test koşulları ile bir tesis veya fabrikadaki fiili durum arasında farklılıklar söz konusudur. Bu nedenle, işlenen gerçek toz (veya toz kombinasyonları) üzerinde testler yapmak ve ayrıca çalışma alanında deneyimlenen gerçek ortamı (yani sıcaklık, nem, türbülans vb.) mümkün olan en yakın değerlerde simüle etmek önemlidir. Belirli bir malzemenin farklı cihazlarda belirlenen $\mathrm{K}_{\mathrm{St}}$ değerlerinin, ortam koşullarına bağlı olması ve farklılık göstermesi toz patlama şiddetini göreceli olarak ifade eden bir sabit olmasına neden olmaktadır. Genel olarak, $\mathrm{K}_{\mathrm{St}}$ değeri ne kadar büyükse, patlama o kadar şiddetli olmaktadır. $\mathrm{K}_{\mathrm{St}}$ aynı zamanda tozun yanma özelliğinin sınıflandırılmasında kullanılan parametrelerden biridir. Tablo 1'de $\mathrm{K}_{\mathrm{St}}$ değerlerine göre tozların sınıflandırılması verilmektedir [16].

Tablo 1. $K_{\mathrm{St}}$ Değerine Göre Toz Patlama Sınıfları [15]

\begin{tabular}{ccc}
\hline Toz Patlama Sinıfi & $\begin{array}{c}\mathbf{K}_{\mathrm{St}} \\
(\text { bar.m/s) }\end{array}$ & Karakteristik \\
\hline St 0 & 0 & Patlamaz \\
St 1 & $>0$ ve $<=200$ & Zayıf Patlayıcı \\
St 2 & $>200$ ve $<=300$ & Kuvvetli Patlayıcı \\
St 3 & $>300$ & Çok Kuvvetli Patlayıcı \\
\hline
\end{tabular}

\subsection{Toz Özelliklerinin Patlama Olayına Etkisi}

Toz metalürjisi ve bağlı teknolojilerinde meydana gelen toz patlama olaylarını doğru bir şekilde analiz edebilmek ve gerekli önlemleri alabilmek için toz bilimi ve uygulamalarını doğru bir şekilde analiz etmek gerekmektedir. Bu nedenle parçacık veya toz karakterizasyonu, toz mekaniği, kırma, öğütme ve aşındırma yoluyla ince parçacıkların üretimi ve toz bulutu oluşumu gibi konular üzerinde yoğunlaşılmalıdır.

Genel olarak bir toz bulutu içerisinden parçacık boyutu ne kadar küçük ise toz bulutunun tutuşabilirliği o kadar kolay ve patlama şiddeti daha yüksek olmaktadır. Yanma prosesinin temelinde yanıı bir gaz ile havadaki oksijen reaksiyonu söz konusudur. Partikül boyutu gazlaştırma sırasında güçlü bir etkiye sahiptir, daha küçük parçacıklar, geniş yüzey alanları nedeniyle hızla gazlaştırılabilir [17]. En az 1 mm'ye kadar olan partikül boyutu ölçümleri, metal tozlarının tutuşabilirliği ve patlayabilirliği açısından büyük önem taşımaktadır. Mikron ve nano seviyedeki partiküllerin toz patlaması riski daha fazladır. Ancak toz boyutu ve risk oranının sonsuz bir doğrusal ilişkide gideceği konusunda bir kesinlik söz konusu değildir ve sınırlayıcı bir alt boyutun olduğu belirtilmektedir [18]. Alüminyum için parçacık boyutunu nanometre aralığına düşürmenin aglomerasyon etkisi sayesinde daha düşük $\mathrm{K}_{\mathrm{St}}$ değerinin elde edildiği çalışmalar mevcuttur $[16,19]$.

Partikül boyutunun yanı sıra şekilleri de yanma karakteristiğine etki eden parametrelerdendir. Bagaria P. ve diğerlerinin yapmış oldukları çalışmada benzer kimyasal bileşime, partikül boyut dağılımına sahip küresel şekilli ve düzensiz şekilli alüminyum tozları seçilmiştir. Sonuçlar, düzensiz şekilli tozun minimum tutuşma enerjisinin (MTE), küresel şekilli tozun MTE'sinden daha düşük olduğunu göstermektedir. Bu değer bir toz patlamasını başlatmak için gereken en az miktarda kıvılcım tutuşturma enerjisini ifade etmektedir [6,20]. Düzensiz şekilli parçacıklar, toz bulutu dinamiklerini etkileyen ve daha düşük iletken 1sı direncine yol açan daha geniş bir özgül yüzey alanına sahiptir, böylelikle tozun tutuşmasını ve alevin yayılmasını kolaylaştıırı. Partikül morfolojisinin MTE değeri üzerine etkilerinin incelenmesiyle daha az tehlikeli formdaki tozun işlenmesi için rehberlik sağlanabilir [21]. 
Toz boyutu parametresiyle ilgili olarak verilebilecek diğer bir örneklem ise ultra ince parçacıklar $(<1 \mu \mathrm{m})$ piroforik özellikte (yani hava ile temas ettiklerinde kendiliğinden yanabilirlik) olmasıdır. Örneğin ince alüminyum parçacıkları, St3 sınıflandırmasına karşıllık gelen yüksek $\mathrm{K}_{\mathrm{St}}(>300 \mathrm{bar} . \mathrm{m} / \mathrm{s})$ ve $\mathrm{P}_{\max }(>10$ bar) değerleri ve düşük minimum tutuşma enerjisi (MTE $<10 \mathrm{~mJ}$ ), bu tür alevlenmelerin önlenmesini ve hafifletilmesini zorlaştırır [20].

\section{TOZ PATLAMASI TETIKLEYICILERI}

Teorik olarak ele alındığında, toz patlaması tehlikesi proseslerde yapılan düzenlemeler ve önlemler ile ortadan kaldırılabilir, ancak pratikte, bu tür modifikasyonlar yapılması çoğu endüstriyel kurum açısından ekonomik bir zorluk olarak görülmektedir. Bu durumda toz patlaması kalıcı bir tehlike haline gelmektedir. Yüksek maliyetli düzenlemelerin mümkün olmadığı durumlarda imkanlar dahilinde ilk adım önlemlerinin alınması gerekir. İlk adım patlamayı tetikleyen faktörleri (parlama noktalarını) belirlemek ve bu faktörlerin devreye girmesini önlemektir. Bir toz patlamasını tetikleyebilecek olan nedenler, alev ve doğrudan ısıya maruz kalmak, sıcak iş uygulamaları ve sıcak yüzeyler, elektrostatik ve elektriksel kıvılcımlar, statik elektrik, sürtünme ısısı sonucunda oluşan kıvılcımlar, kendi kendine 1sı oluşturan prosesler, yıldırım olarak sayılabilmektedir. Bu tutuşturma kaynakları sıcaklık, enerji ve güç açısından farkl1lık gösterir; tozlar özelliklerine bağlı olarak düşük enerjili ve yüksek enerjili tutuşma kaynakları ile tutuşabilir.

\subsection{Alevler ve Doğrudan Isinma}

Isı kaynakları arasında en belirgin olan çeşittir. Sistemdeki ısı kaynağının dolaylı kaynaklar sistem uzaklaştırılması ile önlem alınabilir. Sıcak su veya buharın borulardan sirküle edilmesi ve sıcak su / buhar banyolarının kullanılması gibi dolaylı 1sıtma yöntemleri kullanılarak risk azaltılabilir.

\subsection{Kendi Kendine Istnma}

Ekzotermik reaksiyonlar nedeniyle kendiliğinden ssınma veya kendiliğinden yanma meydana gelebilmektedir. Çok çeşitli reaksiyonlar kendi kendine ısınmaya neden olabilir. Bunlar, oksidasyon reaksiyonlarının yanı sıra belirli tozların su veya ahşapla reaksiyonunu içerir. Nispeten düşük sıcaklıklarda oksidasyon yoluyla kendi kendine 1sınabilen malzemelerin örnekleri arasında ABS reçine tozu, aktif karbon, kömür ve çeşitli kimyasal ara maddeler bulunmaktadır. Bu tür reaksiyonların başlama süreleri uzun ve ilerleme hızları yavaş olabilmektedir. Yağ ve termal bozunma gibi ürünler de kendi kendine isınma sürecine katkıda bulunabilir. Depolama ve işlem süreci sırasında yüzey sıcaklık kontrolünün sağlanması önemlidir. Özellikle tozun kuru tutulması amacıyla yüksek bir sıcaklık ile depolanmaya başlandığı durumlar daha çok dikkat gerektirir. Kurutucudan gelen sıcak tozun hazneye boşaltılması sırasında kaza riski daha da artar. Depolamadan önce tozun soğutulması gerekebilir. Farklı numune boyutları ve bileşimleri için kendi kendine ısınma başlangıç sıcaklıklarını belirlemek için çeşitli laboratuvar testleri geliştirilmiştir. Bunlar, izotermal bir firında toz paketi testi, yavaş bir hava sıcaklığı artış hızıyla 1sıtılmış hava akışı testi ve kendiliğinden hızlanan ayrışma sıcaklığını belirlemek için bir paket testidir. Laboratuvar verilerinin ve ölçeklendirme denklemlerinin kombinasyonu daha sonra kendi kendine ısınmayı ve kendiliğinden tutuşmayı önlemek için uygun tesis seviyesinde önlemleri oluşturmak amacıyla kullanılabilir [14,22]. 


\subsection{Sicak Iş̧ Prosesleri ve Yüzeyler}

Kaynak ve kesme gibi işlemler sırasında üretilen aşırı 1sı, işlem yapılan çevre etrafındaki düşük tutuşma eşiğine $\left(100-200{ }^{\circ} \mathrm{C}\right)$ sahip toz olduğunda bir başka belirgin tetikleyicidir. Kazalar genellikle bu tehlikenin farkına varılmadığı ve sıcak iş başlamadan önce ekipmandaki toz temizlenmediği için meydana gelir.

Buhar borusu veya elektrik lambası gibi sıcak bir yüzeye sahip ekipmanlar veya aşırı ısınmış hareketli ekipmanlar, bu kategoriye girmektedir. Bir toz tabakasının tutuşmasına neden olabilecek yüzey sıcaklığı genellikle 100-200 ${ }^{\circ} \mathrm{C}$ aralığındadır. Tutuşma sıcaklığı, tabakanın kalınlığı arttıkça bu aralığın alt sınırına yaklaşır. Bunun temel sebebi tozların zayıf bir ısı iletken olması ve ekipman üzerindeki toz tabakasının artmasıyla atmosfere 1sı kaybı̈ ölenerek ve toz yığını altındaki yüzey sıcaklığının, toz tutuşma noktasına yükselmesidir. Sıcak yüzey üzerinde biriken bir toz yığının yanma özellikleri de farklılık göstermektedir. Bazı tozlar doğrudan katı fazda alevle veya için için yanarken, bazıları sıvı olarak erir ve yanar. Bazı tozlar ise büyük miktarlarda yanıcı gazlar açığa çıkarabilir. Farklı tozların ürettiği alevlerin boyutları da değişiklik göstermektedir. Pompa ve motor gibi makinelerde yaşanan sıkıntılar sonucunda sıcak yüzeyler de oluşabilir. Bu durumlarda yüzey sıcaklıkları gibi özelliklerin izlenmesi gerekebilir.

\subsection{Akkor Malzeme}

Yanan parçacıklar veya diğer akkor malzemeler, toz işleme ekipmanının içinde bir toz patlamasına neden olabilir. Patlama daha sonra kanallardan ve bağlı parçalardan geçebilir. Doğrudan ateşleme sistemleri, akkor parçacıkların potansiyel kaynaklarıdır. Doğrudan ateşlemeli kurutucularda, bu tür akkor malzemenin girişini önlemek için hava girişi ince bir ara tabaka ile korunmalıdır.

\subsection{Elektrostatik Klvılcımlar}

Elektrikli ekipmandan elektrostatik deşarj, bir kıvılcıma neden olabilir ve bu da bir toz bulutunu tutuşturabilir. Elektrikli ekipman, tahrik kapasitesi veya endüktif deşarj oluşmayacak şekilde tasarlanmalıdır.

\subsection{Elektrik Klvılcımları}

Anahtarlı ve rölelerin normal çalışmasında ve arızalı elektrikli ekipmanlarda elektrik kıvılcımları meydana gelir. Bu tipteki ekipmanların tercihinde özellikle aleve dayanıklı olan ve toz geçirmez ve tamamen tozu dışarıda tutan ekipman tercih edilmelidir. Elektrikli ekipman ve kablo tesisatı, toz bulutlarını kıvılcımlar, arklar veya ısıtılmış yüzeylerle tutuşturabilecek kaynaklardır.

\subsection{Sürtünme Klvllclmlarl}

Sürtünme kıvılcımları, bir katının diğeriyle temas ettiği her yerde veya taşlama sırasında meydana gelebilir. Sürtünme demiri gibi yabancı maddeler de kıvılcımlara neden olabilir. Ayrıca tozun kendisi ekipmanın çalışmasına engel olursa, aşırı yüklenmeye neden olarak kıvılcım oluşturabilir. Sürtünme kıvılcımlarını önlemek için, toz akışı kontrol edilmeli ve makine aşırı yüklemeyi engelleyecek şekilde tasarlanmalıdır. Yabancı cisimlerin 
uzaklaştırılması, özellikle malzeme taşınımı sırasında manyetik veya pnömatik ayırma işlemleri gerçekleştirilmelidir. Toz taşıma ve karıştırma işlemleri sırasında tozun ısınması da sürtünme kaynaklı bir ısı kaynağı olabilir. Öğütücüler, çekiçli değirmenler ve diğer boyut küçülttme ekipmanı özellikle çalışma sırasında tutuşmaya eğilimlidir. R. Eckhoff tarafından açıklanan tek darbeli kıvılcım ateşleme deneyleri, bir mısır nişastası toz bulutunun tutuşma olasılığının artan darbe enerjisi ile arttığını ve aynı zamanda çarpma hızına da bağlı olduğunu göstermiştir. Daha düşük hız darbeleri, belirli bir çarpma enerjisi için daha yüksek hız etkilerinden çok daha büyük bir tutuşma olasılığı üretmiştir. Darbeye maruz kalan metal kombinasyonları da tutuşma olasılığında önemli bir rol oynamaktadır. Çelik-çelik darbeleri ve alüminyum-çelik darbeleri mısır nişastası toz bulutlarını tutuşturmazken, paslı çeliğe karşı titanyum darbeleri kabaca $10 \mathrm{~mJ}$ 'nin altında MTE değerlerine sahip tozları tutuşturabilmektedir.

\subsection{Statik Elektrik}

Statik elektrik, bir nesnenin belirli bir alana hızla girip çıkmasıyla kıvılcımlara dönüşebilir. Bazı toz işleme tesislerinde, statik elektrik kolayca üretilir. Üretim noktaları değirmenleri, konveyör bantlarını ve pnömatik taşıma sistemlerini içerir. Zayıf iletken bir boru kullanılarak yapılan uzun mesafeli taşımalarda, yüklü parçacıkların boru sisteminin boşaltılmamış bölümüne akışı ve yüklü parçacıkların yüklü bölüme akışı sürekli olarak tekrarlanır ve bu statik elektriklenmeyi etkiler [23]. Bir toz bulutunun statik elektrik tarafından tutuşması, partikül boyutu dağılımı ve ateşleme enerjisi uygulama süresinden ve hızından önemli ölçüde etkilenir. Ayrıca kanallarda kullanılan plastik gibi yüzeyler ve tozları taşımak için kullanılan çantalar kıvılcıma neden olabilir. Tozun polietilen torbalardan yanıcı çözücülere dökülmesi sırasında oluşan kıvılcımlar çeşitli kazalara yol açmıştır. Tozların manuel olarak taşınmasında, tozun minimum tutuşma enerjisi $25 \mathrm{~mJ}$ 'den az ise insan vücudundan statik elektrik tehlikesi önem kazanır. Neyse ki, tozların genellikle yüksek minimum tutuşma enerjisi belirtilen seviyenin üzerinde olması ve tozların korona deşarjı verme eğilimi bu tip kaynaklı riskin azaltılmasına katkıda bulunmaktadır. Risklerin azaltılmasının diğer yolları da uygun topraklama sistemlerin tasarlanması, malzeme giriş depolama kutuları üzerindeki pasif boşaltıcıların bulundurulması, insan vücudunun kıvılcım oluşturmasını önlemek için elektrostatik dağıtıcı (ESD) antistatik ayakkabılar ve iletken zeminler kullanılmasıdır. Taşınan tozun minimum tutuşma enerjisi 10 mJ'den azsa, antistatik zemin döşenmesi ve antistatik giysi ve ayakkabı kullanılması zorunludur [14].

\section{TOZ PATLAMASINDA DOMINO ETKİSI}

Domino etkisi, bir birincil kazanın ikincil kazaları tetiklediği ve kaza sonuçlarının insan ve mal kayıpları açısından birincil kazadakinden çok daha ağır olan bir kaza zincirini ifade etmektedir (Şekil 2). Üretim tesislerinde, genellikle yüksek basınç ve yüksek sıcaklık koşulları altında büyük yanıcı ve patlayıcı madde envanterleri içeren birçok büyük tehlikeli tesisin varlığı nedeniyle, birincil bir kazanın bir domino etkisine dönüşmesi olasıdır. Birincil toz patlaması olasılığını ortadan kaldırmaya çalışmak önemli olsa da, ilk patlamanın bir dizi başka patlamayı başlatması olasılığını azaltmak daha da önemlidir. İkincil / üçüncül toz patlamaları genellikle birincil patlamanın meydana geldiği yerden uzakta gözlemlenir. Proses tesisinin farklı birimlerinde birincil ve ikincil toz patlamaları meydana gelebileceğinden, bazen birincil patlama tarafından üretilen basıncın ve alevin yayılmasını engellemek için farklı tehlikeli birimler arasında güvenlik bariyerlerinin uygulanması domino etkisi olasılığını azaltmak için 
alınan önlemlerden biri olmasına rağmen birçok durumda, bu tür güvenlik önlemlerinin uygulanması, sınırlayıcı operasyonel hususlar nedeniyle zor olmaktadır. Tipik bir örnek olarak, 2003 yılında ABD'deki CTA Acoustics firmasında meydana gelen fenolik reçine tozu patlamasıdır. İlk (birincil) toz patlaması, üretim hattında (405) meydana gelirken, ikincil toz patlaması, ilk patlamadan $25 \mathrm{~m}$ daha uzakta olan 401 hattında gerçekleşmiştir [24,25]. Domino etkisinin ismini aldığı domino devrilmesi oyununu oluşturan mükemmel domino etkisinde, her bir dominonun bir sonrakini devirdiği ivme, ilk vuruştan itibaren (momentum bir sonraki domino taşını devirmek için yetersiz olduğu değere ulaşana kadar) istikrarlı bir şekilde azalmaya devam ederken, toz patlama olayındaki domino etkisi, zincir ilerledikçe azalma yerine yükselen değerler ile karakterize edilir [26].

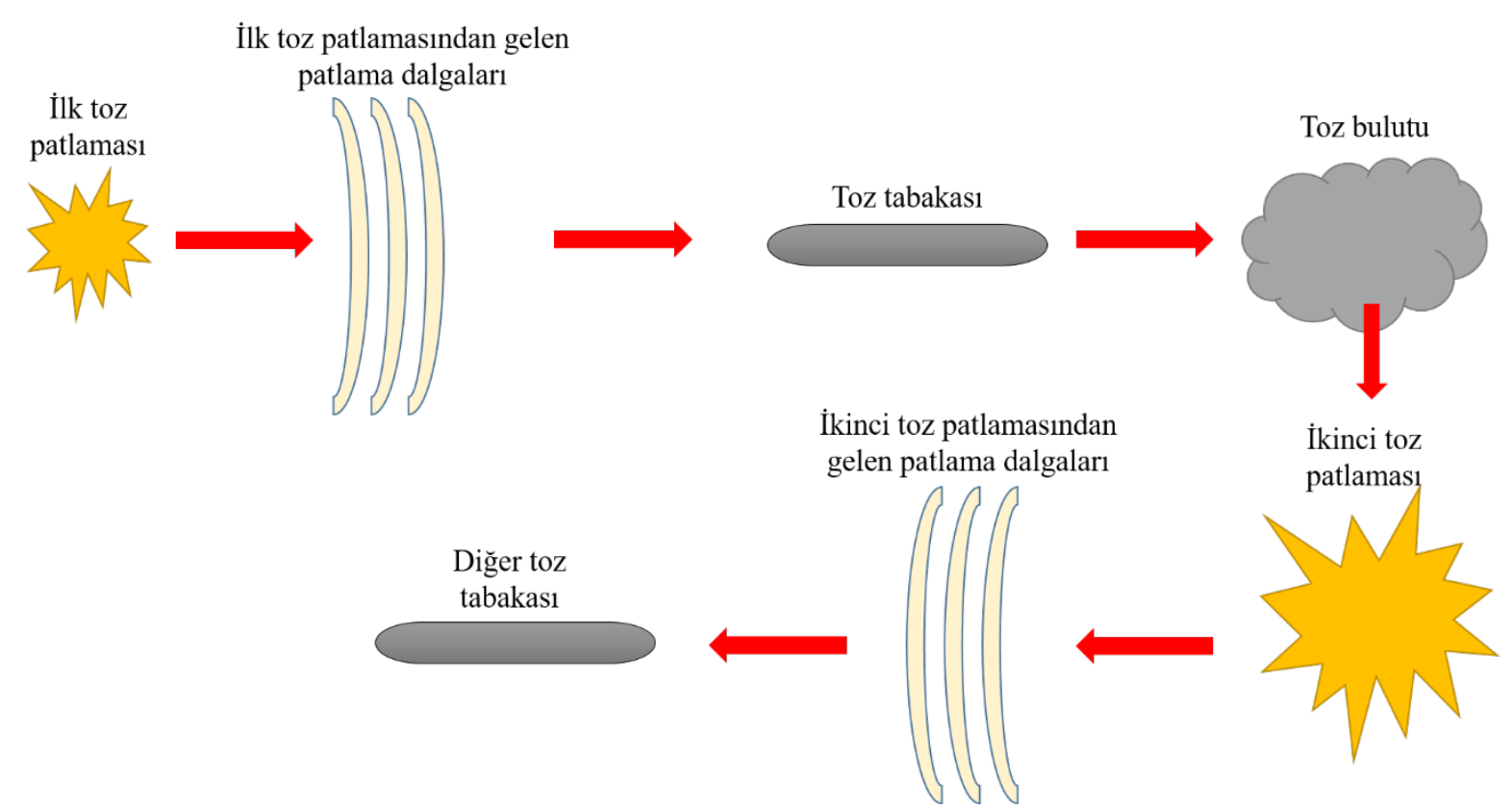

Şekil 2. Toz patlamasında domina etkisi [28]

\section{EKLEMELİ İMALAT TEKNOLOJISINDE TOZ PATLAMASI RİSKI}

Üç boyutlu baskı, hızlı üretim veya Eİ olarak da bilinen yöntem, Amerikan Test ve Malzeme Kurumu (ASTM) tarafından "Üç boyutlu model verilerinden nesneler yapmak için genellikle katman üzerine katman şeklinde malzemeleri birleştirme işlemi” olarak tanımlanmaktadır. Eİ teknolojisi, son yıllardaki gelişmelerle birlikte yalnızca plastik, kâğıt veya betondan değil, aynı zamanda kompozit malzemelerden veya metallerden de çeşitli bileşenler ve nesneler üretilen endüstrilerde yer almayı başarmıştır. Eİ teknolojisi geleneksel üretim teknolojilerine kıyasla daha iyi mekanik özellikler elde edilebilmesi, geleneksel üretim süreçlerini kullanarak üretilmesi neredeyse imkânsız olan çok karmaşık şekiller ve yapılar oluşturabilmesi gibi avantajlara sahip olmasına rağmen, çalışanların sağlığı ve çevre etkileri açısından sınırlamaları ve tehlikeleri bulunmaktadır [28]. Bu tehlikelerin eklemeli imalat süreçlerine göre sınıflandırılması Tablo 2'de verilmektedir. Uygulamalardaki ve benimsenmedeki çarpıcı artışa rağmen, toz metalürjisi ve Eİ teknolojilerinin işçi güvenliği ve sağlığı üzerindeki potansiyel etkileri hakkında yayınlanan az miktarda akademik literatür bulunmaktadır [29].

Eİ üretim yöntemleri, hammadde malzemeleri, hammadde biçimi (sıvı, katı veya toz gibi faz veya durum), işlemler (malzemeleri bağlamak için kullanılan mekanik kuvvetler ve enerjiler) ve makine mimarisi esas alınarak 
tanımlanır. Yönlendirilmiş enerji biriktirme ve toz yatağı füzyon gibi Eİ proseslerinde, bir lazer veya bir elektron 1şını, hedef malzemenin erimesi beklenen noktayı hedeflemektedir. Ancak bir ısı kaynağı olarak bir lazer veya bir elektron 1şını kullanmak, sistemin bir inert gaz veya yüksek bir vakum kombinasyonundan oluşmasını gerektirir; bu nedenle, hazneye verilen hasar sonunda bir patlamaya yol açabilir. En önemlisi, ikincil patlamalar, artan miktar ve dağılmış yanıcı toz konsantrasyonu nedeniyle birincil patlamadan çok daha yıkıcı olabilir. Bunlar potansiyel olarak ölümlere ve yaralanmalara ve hatta bir üretim tesisinin tahrip olmasına neden olabilir [30,31]. Eİ ve geleneksel teknolojiler arasında benzerlikler olsa da, malzemelerdeki, uygulamalardaki ve iş organizasyonundaki değişiklikler, tamamen yeni olan veya yeniden değerlendirmeyi gerektirecek kadar farklı olan potansiyel tehlikeler yaratabilir. Bu süreç kategorilerinin bir özeti ve potansiyel olarak ortaya çıkan tehlikelerin bir listesi aşağıdaki tabloda verilmektedir.

Tablo 2. Eklemeli imalat süreç kategorisine göre ilgili potansiyel tehlikeler [29]

\begin{tabular}{|c|c|c|c|c|}
\hline Yöntem & Hammadde malzemeleri & Hammadde formu & $\begin{array}{c}\text { Hammadde } \\
\text { bağlama/kaynaştırma } \\
\text { yöntemi } \\
\end{array}$ & $\begin{array}{c}\text { En belirgin } \\
\text { potansiyel tehlikeler }\end{array}$ \\
\hline Malzeme Ekstrüzyonu & Termoplastikler & $\begin{array}{l}\text { Makaralı filament, pelet } \\
\text { veya granül }\end{array}$ & $\begin{array}{l}\text { Elektrikli ısıtma } \\
\text { kaynaklı } \\
\text { eritme/soğutma }\end{array}$ & $\begin{array}{c}\text { Organik uçucu } \\
\text { bileşenlere (OUB), } \\
\text { partiküllere, katkı } \\
\text { maddelerini soluma } \\
\text { maruziyeti, yanıklar }\end{array}$ \\
\hline $\begin{array}{l}\text { Toz Yatak } \\
\text { Kaynaştırma }\end{array}$ & Metal, seramik veya plastik & Toz & $\begin{array}{c}\text { Yüksek güçlü lazer } \\
\text { veya elektron 1şını } \\
\text { 1sıtma }\end{array}$ & $\begin{array}{c}\text { Toza, dumana soluma } \\
\text { maruziyeti; patlama; } \\
\text { lazer/radyasyona } \\
\text { maruz kalma } \\
\end{array}$ \\
\hline Stereolitografi & Fotopolimer & Siv1 reçine & $\begin{array}{l}\text { Ultraviyole lazer } \\
\text { kaynaklı kürleme }\end{array}$ & $\begin{array}{c}\text { OUB'lerin solunması; } \\
\text { reçinelere ve } \\
\text { solventlere maruz } \\
\text { kalma, ultraviyole } \\
\text { maruz kalma } \\
\end{array}$ \\
\hline Malzeme Jeti & Fotopolimer veya balmumu & Sıvı mürekkep & $\begin{array}{l}\text { Ultraviyole } 1 \text { şık } \\
\text { kaynaklı kürleme }\end{array}$ & $\begin{array}{c}\text { OUB'lerin solunması; } \\
\text { reçinelere ve } \\
\text { solventlere maruz } \\
\text { kalma, ultraviyole } \\
\text { maruz kalma } \\
\end{array}$ \\
\hline Binder Jeti & $\begin{array}{c}\text { Metal, seramik, plastik } \\
\text { veya kum }\end{array}$ & Toz & Yapıştırıcı & $\begin{array}{c}\text { Toz soluma } \\
\text { maruziyeti; patlama; } \\
\text { OUB'lerin solunması, } \\
\text { bağlayıcilara cilt } \\
\text { yoluyla maruz kalma }\end{array}$ \\
\hline Katman Laminasyonu & Metal, seramik veya plastik & $\begin{array}{c}\text { Haddelenmiş film veya } \\
\text { levha }\end{array}$ & $\begin{array}{l}\text { Yapıştırıcı veya } \\
\text { ultrasonik kaynak }\end{array}$ & $\begin{array}{c}\text { Dumanların } \\
\text { solunması, OUB'ler; } \\
\text { şok, lazer/radyasyona } \\
\text { maruz kalma } \\
\end{array}$ \\
\hline
\end{tabular}

Eİ teknolojilerinde alüminyum, titanyum, magnezyum gibi birçok metal tozu ve alaşım tozları kullanılmaktadır. Bir metalin alaşımlanması, yanıcılık / patlayıcılık ve diğer parçacık dinamikleri dahil olmak üzere malzemenin özelliklerini değiştirir. Yanıcı bir tozun küçük partikül boyutu veya geniş yüzey alanı / hacim oranı, onu yanıcı bir katıdan ayıran şeydir. Yığın katıların yanma hızı tipik olarak oksitleyici (hava) ile temas halindeki katının yüzey alanıyla sınırlıdır ve bu nedenle bir malzemenin parçacık boyutu küçüldükçe, özgül yüzey alanı artar ve malzeme kütlesi başına yanma hızı artar. Toz metalurjisinin (TM) ve eklemeli üretim (Eİ) tekniklerinin popülaritesindeki artış, metallerin toz formunda kullanımını artırmakta ve geleneksel kodlar ve standartlar tarafından açıkça kapsanmayan yeni işleme teknikleri açığa çıkarmaktadır. TM ve Eİ tipik olarak çok küçük ortalama partikül çaplarına sahip oksitlenmemiş metal tozlarının kullanımını içermektedir. Küçük parçacık boyutu nedeniyle, bu tozlar çok düşük minimum ateşleme enerjilerine sahip olma eğilimindedir. Proses çoğu zaman tozların 
depolanması, aktarılması, işlenmesi ve 1sıtılmasını gibi adımları içerir, bu durum da ekipman ve personel için özel önlemlerin alınmasını gerektirir. Yanıcı metal tozlarının geleneksel organik yanıcı tozlara kıyasla daha farklı zorlukları söz konusudur. Bunlar;

- Bazı yanıcı metal tozları, $4500{ }^{\circ} \mathrm{C}$ kadar yüksek yanma sıcaklıklarıyla hidrokarbon bazlı tozlardan çok daha sıcak yanabilir [32,33].

- Bazı yanıcı metaller, çoğu organik toza kıyasla bir parlama sırasında (parlama indeksi, $\mathrm{K}_{\mathrm{st}}$ ile ölçülen) çok daha hızlı basınç artışları üretebilir. Örneğin alüminyum ve magnezyum metal tozları, literatürde bildirilen en yüksek $\mathrm{K}_{\mathrm{St}}$ değerlerinden bazılarına sahiptir [8,33,34].

- Birçok yanıcı metal su ile reaksiyona girdiğinden dolayı ve su yangın söndürme aracı olarak kullanılamaz. Ayrıca metal tozları için yangın söndürme sistemlerinin standardizasyonu zordur çünkü bazı yanıcı metal tozları, su veya karbondioksit gibi geleneksel yangın söndürme maddeleriyle uyumlu değildir.

- Büyük miktarlarda yanıcı metal tozu içeren yangınları söndürmek son derece zordur ve genellikle malzemenin kendi kendine yanmasına izin verilmesini gerektirir.

- Metal tozlarının yüksek yanma sıcaklıkları ve $\mathrm{K}_{\mathrm{St}}$ değerleri nedeniyle patlama bastırma ve izolasyon sistemi tasarımı karmaşıktır.

- Yanıcı metal tozları, bir termit reaksiyonunda diğer metallerin oksitleri ile ekzotermik olarak reaksiyona girebilir. Bu nedenle yanıcı metal tozları diğer metaller için kullanılan ekipmanlarda işlenmemeli veya taşınmamalıdır $[8,35]$.

Eİ alanındaki birincil güvenlik endişelerinin çoğu, ince metal tozu besleme stoklarının (tipik olarak $10 \mu \mathrm{m}$ ile 250 $\mu \mathrm{m}$ çap arasında) kullanılmasından kaynaklanmaktadır; bu tür parçacıklar, yığın halindeki besleme stoğu malzemesine göre reaktivitelerini artıran yüksek bir yüzey alanı/hacim oranına sahiptir. Bu yüksek reaktivite, bu hammaddelerin çoğunu aerosol haline getirildiğinde yanıcı ve hatta patlayıı hale getirebilir ve toz parçacıklarının solunmasını operatörler için tehlikeli hale getirebilir.

Eİ'de halihazırda kullanılan çok çeşitli metalik tozlar vardır. Toz seçimi, ürünün istenen özelliklerine ve kullanılan Eİ teknolojisine bağlıdır. Eİ'de kullanılan yaygın metal tozlarından bazıları nikel, çelik, alüminyum, kobalt-krom ve titanyum alaşımlarıdır. Metal tozlarının çoğu, metal ürünler üzerinde yapılan birim operasyonların yan ürünleridir ve sağlık nedenleriyle çalışma ortamından toplanmaları ve uzaklaştırılmaları gerekir. Çoğu durumda, kimyasal yapıları işlenmekte olan ürünlerin kimyasal bileşiminin doğrudan bir sonucudur, ancak havada yüksek bir sıcaklık anlamına gelen bu işlemler, partiküllerin kısmi oksidasyonunu belirleyebilir ve bu da onların reaktivitesini azaltır. Örneğin, alüminyum alaşımlarından oluşan numuneler, oksit içerikleri çoğunlukla demir alaşımlarından oluşan diğer toz türlerinden daha fazla olmasına rağmen yüksek $\mathrm{K}_{\mathrm{St}}$ değerleri göstermektedir. $\mathrm{Bu}$ sonuç, alüminyumun diğer birçok metale göre yüksek reaktivitesini doğurur. Alüminyumun oksijene yüksek afinitesi nedeniyle, tozun olası tutuşmasını veya havada asılı kalan ince toz fraksiyonunun patlamasını önlemek için dikkatli olunmalıdır. Şekil 3’te farklı morfolojideki alüminyum toz şekillerinin, toz bulutu MTE ve patlayabilirlik üzerindeki etkisini araştırmak için kullanılan üç farklı tozun taramalı elektron mikroskobu görüntüleri verilmiştir. Tablo 3’te çeşitli şekil yapılarınsa sahip alüminyum tozlarının yanma özellikleri ifade edilmiştir. Artan partikül şekli düzensizliğine sahip alüminyum tozlar, parlama hassasiyetinin (daha düşük MTE) ve şiddetinin (daha yüksek $\mathrm{K}_{S t}$ ve $\mathrm{P}_{\max }$ ) net bir şekilde arttığını göstermiş̧tir. Bu durum düzensiz morfolojiye sahip parçacıklara sahip toz bulutları içindeki bitişik parçacıkların ışınımsal ısı transferi etkileriyle tutuşma olayları için 
bir potansiyel sunmasından kaynaklanabilmektedir. Parçacık şekli ve spesifik yüzey alanı, dikkate alınması gereken temel faktörlerdir ve bunların değerlendirilmesi, pnömatik taşıma ve metal tozu işleme endüstrileri için gerçekleştirilen risk/tehlike analizi sırasında standart prosedür olarak kabul edilmelidir [38]. Ayrıca toz halindeki malzemelerin partikül boyutunun yanma özelliklerine etkileri incelendiğinde yalnızca medyan çapının (D50) değil, aynı zamanda tüm parçacık boyutu dağılımının önemli olduğu görülmektedir. Toz boyut dağılımı D10, D50 ve D90 ile ifade edilmektedir. D10 tozların \%10'unun, D50 tozların \%50'sinin ve D90 tozların \%90'inın hangi boyutun altında olduğunu göstermektedir. Bununla birlikte, birçok durumda, kümülatif dağılım eğrisinin yalnızca D10, D50 ve D90 yüzdelikleri verilir. Dağılım/yığılma sırasında toz yoğunluğu ve efektif partikül boyutu da değişeceği için, yanma özelliklerinin de değişmesi kaçınılmazdır. Partikülleri homojen dağılmış tozlar çok daha iyi yanma göstermektedir. Dağılım derecesi, genellikle tozun dağılım şekline ve toz bulutu içindeki türbülans derecesine bağlıdır. Son yıllarda, bu malzemelerin partikül boyutu dağılımını karakterize etmek için polidispersite indeksi önerilmiştir. Ancak polidispersite indeksinin patlama şiddeti ile tutarlı bir şekilde korelasyon göstermemesi sebebiyle, partikül boyutu dağılımını raporlamak için polidispersite tavsiye edilmemektedir [39].
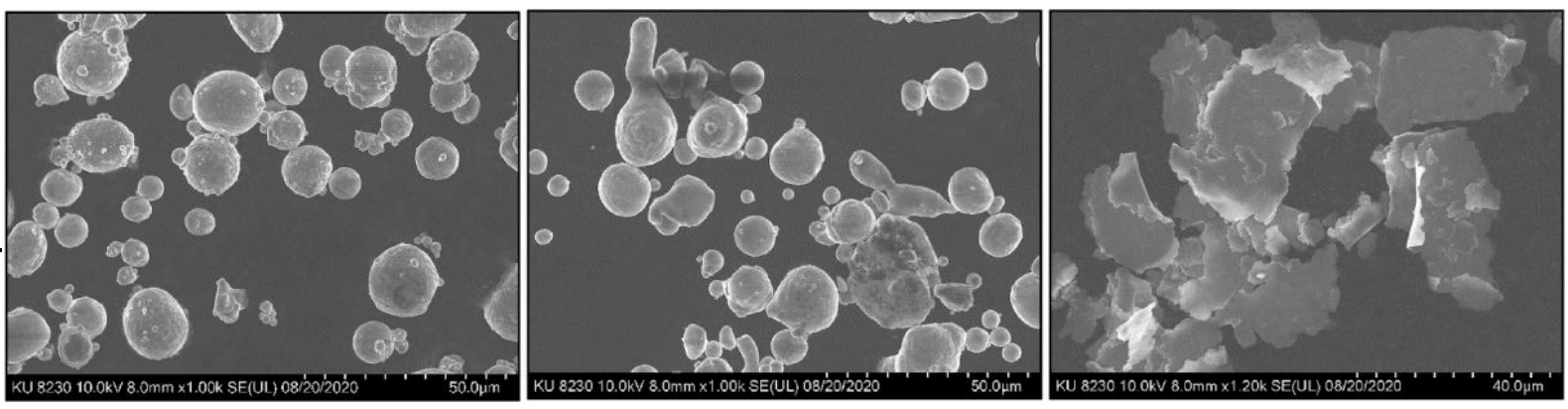

Şekil 3. Tüm alüminyum parçacık morfolojilerinin SEM görüntüleri (küresel [sol], düzensiz [orta] ve pul [sağ]) [38]

Tablo 3. Küresel, düzensiz ve pul alüminyum toz örnekleri için patlama duyarlılığı ve şiddeti sonuçlarının özeti [38]

\begin{tabular}{cccc}
\hline Morfoloji & Küresel Şekilli Alüminyum & Düzensiz Şekilli Alüminyum & Pul Alüminyum \\
\hline MTE $[\mathrm{mJ}]$ & 39 & 21 & 11 \\
$\mathbf{K}_{\mathrm{St}}[$ bar $-\mathrm{m} / \mathrm{s}]$ & 125 & 279 & 545 \\
$\mathbf{P}_{\max }[$ bar $-\mathrm{g}]$ & 7.28 & 8.19 & 9.71 \\
\hline
\end{tabular}

Ayrıca alüminyum tozu üretimi için gaz atomizasyon teknolojisi tehlikeli bir süreçtir ve üretim maliyetlerini önemli ölçüde artıran özel güvenlik önlemleri gereklidir. Alüminyum ve alaşımlarının yükssek 1sıl iletkenliğgi, bunların dökümünü ve kaynaklanmasını zorlaştırır. Toz yatağında difüzyon imalat yöntemi için işler daha da kötüleşir, çünkü alüminyum tozları doğası gereği hafiftir ve yeni katmanın işlenmesi sırasında zayıf akışkanlığa sahiptir. Ayrıca yüksek oranda yansıtıcıdırlar, lazer bazlı Eİ teknolojileri için sorun yaratırlar ve diğer malzemelerle karşılaştırıldığında yüksek termal iletkenliğe sahiptirler.

Eİ imalat teknolojilerinde sıklıkla kullanılan tozlardan biri olan titanyum, en yanıcı metal tozlarındandır. Titanyum patlaması, yalnızca Eİ için değil, titanyumla yapılan tüm kaynaklar için bir risktir. Argon kullanımı patlamayı önler, ancak tozun oksijene maruz kaldığı ve hava akımının tutuşma kaynağı olabileceği havalandırmada risk oluşur. Argon gibi inert gazların kullanılması da sağlık risklerini beraberinde getirir. Gaz havadan ağırdır, bu da oksijen eksikliğinden bayılma riskine yol açar. Kaynakçıların zehirli dumanları ve kaynak partiküllerini soluma riski de vardır. Zeminlerde ve basamaklarda toz birikmesi de kayma ve düşme tehlikesi oluşturur. Bu nedenle, yüz maskeleri ve eldivenler dahil uygun koruyucu giysilerin yanı sıra uygun güvenlik süreçleri de önemlidir [40]. 
Gelişen teknoloji ile birlikte nano boyuttaki metal tozu kullanımı da ilgi çekici hale gelmiştir. Bu konuya yönelik olarak, M. Mittal, yapmış olduğu çalışmada magnezyum nano tozlarının $(<200 \mathrm{~nm})$ patlama şiddetinin mikron tozlarından daha düşük olduğunu, ancak magnezyum nano tozlarının çok düşük tutuşma enerjileri nedeniyle patlama olasılığının oldukça yüksek olduğunu belirtmektedir. Nispeten düşük miktarlar ve çok düşük kıvılcım enerjileri, nano magnezyum tozunun tutuşmasına ve ciddi patlamalara yol açmasına neden olabilir. Mikro ölçekli tozlar için bulunan patlama verileri, nano tozlar için herhangi bir güven ölçeği içerisinde tahmin edilebilir değildir. Bu nedenle NFPA 484'teki (NFPA, 2012) azaltma teknikleri ve tutuşma kaynağından kaçınmaya yönelik hazırlanan bu tür diğer standartlar, nano ölçekli metal tozlar için değiştirilmelidir. Nano tozların patlama tehlikelerini değerlendirmek için, tozları işleyen tesisler için patlama güvenlik önlemleri tasarlamak için her iki ölçekteki malzemenin deneysel veri sonuçlarını gerektirmektedir [37].

Kullanılan yönteme Eİ yöntemine göre potansiyel riskler farklılık oluşturmaktadır. Seçici lazer ergitme, elektron ışın ergitme ve doğrudan ergite gibi toz yataklı Eİ teknolojileri, ağırlıklı olarak bireysel temel veya ön alaşımlı tozların kullanılmasına dayanır. İstenmeyen hapsedilmiş veya adsorbe edilmiş gazlar ve nem, üretilen bileşenlerdeki gözeneklerin kaynağı haline gelir ve Eİ işlemi sırasında reaksiyona girerek mikro yapı sınır yüzeylerinde oksit veya nitrür kapanımları ve katmanlar oluşturabilir. Bu oksitler, ince, doğal olarak zayıf tane sınırları ile sonuçlanır ve Eİ işleme sırasında tek tek toz parçacıkları arasındaki bağlanma kuvvetlerini sınırlar [40].

Gaz atomizasyonu ile üretilen titanyum alaşımlı tozların bir örneğini alarak farklı Eİ sistemlerinin gerektirdiği tipik toz tane boyutu dağılımının incelendiği çalışmada, elektron ışın ergitme, 45 ile $106 \mu \mathrm{m}$ arasında bir nominal partikül boyutu dağılımı kullanırken, seçici lazer ergitme, 15 ile $45 \mu \mathrm{m}$ arasında daha ince tozlar kullanıldığı belirtilmiştir. Parçacık boyutu dağılımı, ilgili Eİ teknolojisinin yetenekleri üzerinde ciddi bir etkiye sahiptir. Daha ince taneli tozlar, pürüzlülüğünü azaltırken baskı çözünürlüğünü artıran katman kalınlığı üzerinde daha iyi kontrol elde edilmesini sağlar. Öte yandan, daha büyük boyutlu toz içeren daha kalın katmanlar, potansiyel olarak daha hızlı üretime olanak tanır. Dağıtımda daha ince toz fraksiyonlarının mevcudiyeti, küçük parçacıklar daha büyük olanlar arasındaki boşlukları doldurmaya yardımcı olduğundan, toz tabakasından üretilen katı metal hacmini arttırdığından daha sıkı bir paketleme yoğunluğuna izin verir. Küçük partiküller (10-15 ㅆm'den küçük) tozun akışkanlığını azaltır ve tozun işlenmesi sırasındaki riskleri artırır. Bu nedenle, yüksek paketleme yoğunluğu ve iyi akış özellikleri elde etmek için parçacık boyutu dağılımında optimum bir değer aralığının seçilmesi gerekmektedir [40].

\section{PROSES GÜVENLİĞİ VE RİSK YÖNETIMİ}

Patlama olayını engellemek için yanma beşgeni içerisinde yer alan unsurlardan birinin kaldırılması yeterlidir. Spesifik olarak değerlendirildiğinde metal tozları organik tozlardan daha yüksek alev sıcaklıkları (Tf) sergiler, ancak partikül boyutu dağılımı ve bir oksit filminin varlığına bağlı olarak daha düşük veya daha yüksek maksimum patlama basınçlarına sahip olabilmektedirler. Metal tozları için yangın söndürme sistemlerinin standardizasyonu zordur çünkü yanıcı metal tozu, su veya karbondioksit gibi geleneksel yangın söndürme maddeleriyle uyumlu değildir. Büyük miktarlarda yanıcı metal tozu içeren yangınları söndürmek son derece zordur ve genellikle malzemenin kendi kendine yanmasına izin verilmesi gerekir. Metal tozlarının yüksek yanma sıcaklıkları ve $\mathrm{K}_{\mathrm{St}}$ değerleri nedeniyle patlama şiddetinin azaltılması ve izolasyon sistemi tasarımı karmaşıktır. Ayrıca yanıcı metal 
tozları, bir termit reaksiyonunda diğer metallerin oksitleri ile ekzotermik olarak reaksiyona girebilir. Bu nedenle yanıcı metal tozları diğer metaller için kullanılan ekipmanlarda işlenmemeli veya taşınmamalıdır [16].
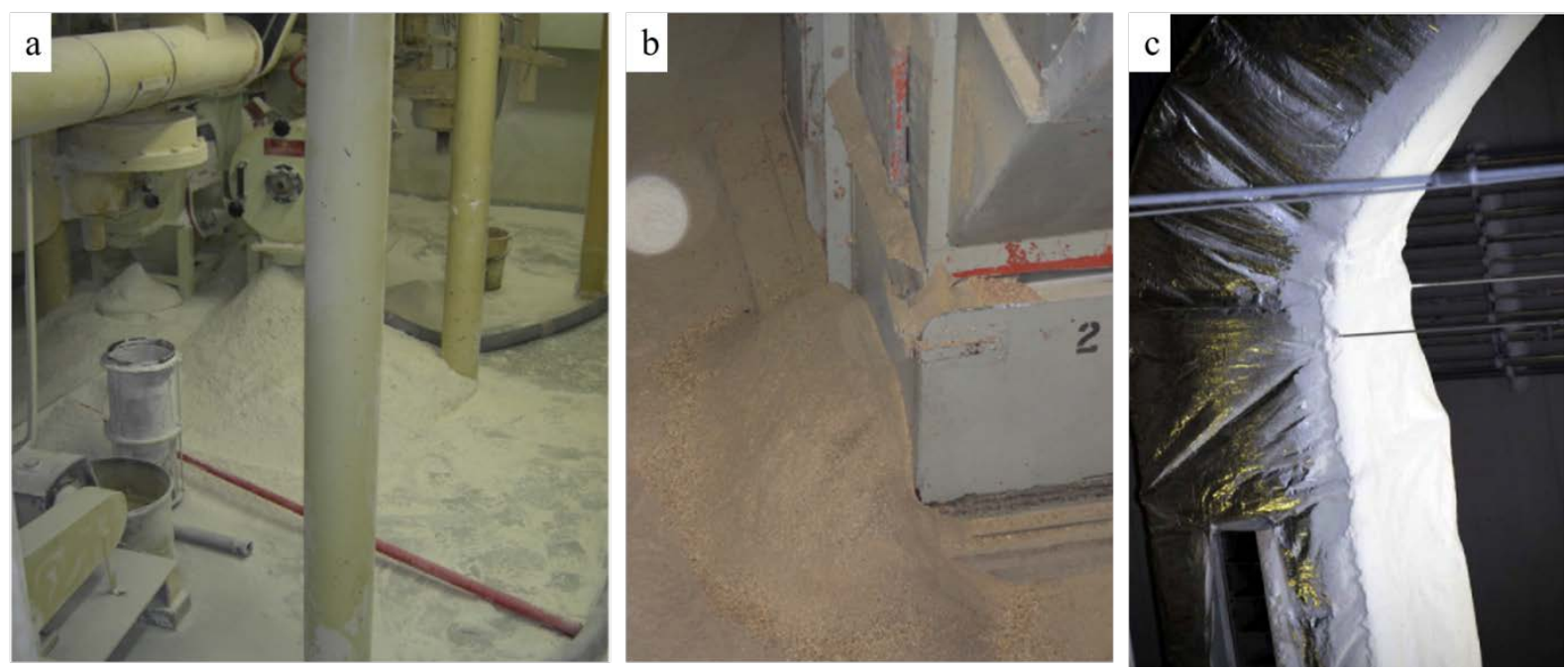

Şekil 4. Silo altında (a) ve proses ekipmanından aşııı malzeme sızması nedeniyle toz tabakası birikmesi (b), kanallar, kirişler, kablo kanalları vb. yükseltilmiş, yatay yüzeylerde toz birikmesi (c) [42]

Doğası gereği daha güvenli tasarım ilkeleri tehlikelerin kaynağında ortadan kaldırılması esasına dayanan bir temel proses güvenliği konseptidir. Genel olarak proses tesislerinde ve özellikle toz patlamalarıyla ilgili olarak bu ilkenin dikkate alınması önemlidir [41]. Toz bulutu patlama risklerini doğru bir şekilde yönetmek için tozun/tozların patlama özelliklerinin anlaşılması, normal ve anormal çalışma koşulları sırasında yanıcı toz bulutu ortamlarının bulunduğu veya bulunabileceği yerlerin belirlenmesi, normal ve anormal koşullar altında bulunabilecek potansiyel tutuşturma kaynaklarının belirlenmesi, toz patlamalarının meydana gelmesini önlemek ve/veya en aza indirmek ve insanları ve tesisleri bunların sonuçlarına karşı korumak için uygun proses ve tesis tasarımı, tutuşturma kaynaklarını ve toz salınımını en aza indirmek için tesislerin yeterli bakımı gibi adımların uygulanması gerekmektedir. Şekil 3’te metal tozunun kullanıldığı tesislerdeki potansiyel tehlike noktaları gösterilmektedir.

Ortam kontrolünü sağlamanın yöntemleri arasında seyreltme havalandırması ve yerel egzoz havalandırma sistemleri yer almaktadır. Seyreltme havalandırması ortamın içine ve dışına temiz hava akışını sağlayarak çalışma alanındaki yanıcı atmosferin arka plan konsantrasyonunu azaltır, ancak salınım kaynağında yanıcı atmosferin kontrolü sağlanamaz. Yerel egzoz havalandırması ise yakıtı tahliye kaynağında durdurmak, atmosferi seyreltmek ve yakıt malzemesini, geri kazanıldığı veya yok edildiği bir sisteme yönlendirecek şekilde tasarlanmıştır. Doğru şekilde tasarlanmış yerel egzoz havalandırma sistemleri, toz bulutu ortamlarının yayılma kaynağının yayılmasını sınırlamada oldukça etkilidir.

Yanmayı oluşturan temel etmenlerden biri de ortamdaki oksijen varlığıdır. Çoğu metal tozu, hava ile temas ettiğinde hızlı bir şekilde oksitlendiğinden ve kimyasal olarak inert bir metal oksit tabakası oluşturduğundan, metal oksit(ler)in erime ve kaynama noktaları ile alev sıcaklıkları dikkate alınmalıdır. İnert bir elementin veya bileşiğin eklenmesi, bir metal tozunun reaktivitesini önemli ölçüde azaltabilir. Metal oksitleri gevrek yapıları nedeniyle tozların işlenmesi sırasında uygun bir seçenek olmayabilir, ancak toz atıkların bertaraf edilmesi sırasında toz partiküllerinin oksidasyonu, özellikle partikül boyutu küçük olduğunda, bir inertleme etkisine neden olacağı için tercih edilebilmektedir İnert bir gaz ekleyerek oksidan konsantrasyonunun yanma oluşumu engelleyecek 
sınırlayıcı oksidan konsantrasyonu (SOK) seviyesinin altına düşürmek önleyici olabilir. Oksidan seviyesini düşürmek için sisteme azot, argon, helyum gibi asal gazlar veya diğer atıl gazlardan karbondioksit ve baca gazı (yerinde proseslerden kaynaklanan atık gaz) sisteme verilebilmektedir. Ayrıca oksidan vakum altında çalışılarak da uzaklaştırılabilir [43].

Çoğu dökme malzemenin aksine, metal tozları sıcaklık ve nem gibi çevresel koşullara duyarlıdır; metal tozu besleme stokları kullanan herhangi bir tesis, iklim kontrollü yeterli depolama kapasitesi sağlayacak şekilde tasarlanmalıdır. Mevcut uygulamaların çoğunda, iki veya üç Eİ makinesi, küçük hacimli kaplar yoluyla metal tozu ile beslendiği bir odada tipik olarak bulunur. Eİ makinelerinin sayısı düşük olduğunda ve yapım süreleri günler aldığında bu kabul edilebilir. Bununla birlikte, Eİ makineleri üretim ortamında kaçınılmaz olarak arttığından ve sırayla hem üretim oranları hem de basılı bileşenlerin boyutu arttıkça, teknik istenen bir gereklilikten ziyade yoğun metal tozlarının etkin bir şekilde tedarik edilmesi esastır. Bununla birlikte, metal tozunun bu etkili transferi için patlama riski ana faktörünün üstesinden gelinmelidir. Metal tozlarının otomatik olarak kapanan yanıcı dolaplarda ve/veya ek yangın geçirmezlik seviyelerine sahip "kontrol alanlarında" saklanması tavsiye edilmektedir ve bazı yetki alanlarında gereklidir. Ek olarak, belirli yetki alanlarında, “yüksek katlı" bir binada depolanabilecek yanıcı katı miktarları için özel kısıtlamalar geçerlidir. Bazı Eİ makinelerinin toz haznelerinin boyutu bu yasal depolama limitlerine yaklaşabileceğinden veya aşabileceğinden, bu kısıtlamalara özel dikkat gösterilmelidir.

Birçok Eİ makine üreticisi, dökülen tozu boşaltmak için anti-statik elektrikli süpürgelerin kullanılmasını önermektedir. Genel olarak, bu vakumların basınçlı hava ve bir topraklama noktasına erişim gerektirdiğini unutulmamalı; toz dökülmesine maruz kalabilecek herhangi bir alan bu göz önünde bulundurularak tasarlanmalıdır.

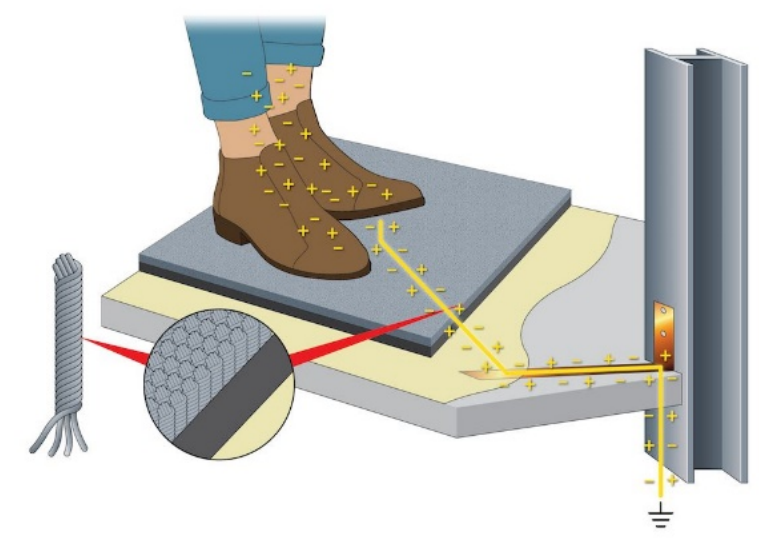

Şekil 5. Toz patlamasını önleme yöntemlerinden biri olan elektrostatik dağııııı zemin kaplaması (ESD) şematiği [44]

Aerosol halindeki toz yangınları için en yaygın tutuşma kaynaklarından biri elektrostatik kıvılcım olduğundan, elektrostatik dağıtıcı (ESD) ayakkabı kayışlarıyla birlikte ESD zemin kaplaması yangın riskini azaltabilir. Düzgün tasarlanmış bir döşeme malzemesinde, statik kontrol özellikleri zeminin kendisi kadar uzun süre dayanmalıdır (Şekil 5). Çoğu iletken ve statik enerji tüketen zeminler, karbon, grafit ve gümüş gibi temel iletken veya enerji tüketen malzemeler kullanılarak üretilir. Birçok Eİ makinesi topraklama kayışları ve antistatik paspaslarla donatılmış olsa da, oda çapında çözümler makine operatörlerine daha fazla hareket kabiliyeti sağlar ve kişisel statik korumanın unutulma olasılığını azaltır. 
Çoğu metal tozu, solunduğunda veya yutulduğunda zararlı olarak kabul edilir. Tam yüz P100 solunum maskelerinin (veya eşdeğer korumanın) kullanılması maruz kalma riskini azaltır ve toz çevreye maruz kaldığında kullanılmalıdır. Metal tozları kullanan tüm ekipmanın uygun işaretler ve erişim kontrolleri olan ve daha kaliteli hava değişim sistemleriyle donatılmış ayrı bir odaya ayrılması, operatör olmayanlara maruz kalmayı önleyebilir, asılı toz parçacıklarının miktarını azaltabilir ve acil çıkış yollarındaki tehlikeleri ortadan kaldırabilir. Temiz oda yapışkan paspasları, laboratuvar dışındaki alanların ve personelin kontaminasyonunu önlemek için operatörlerin ve misafirlerin çalışma alanından çıkarken ayakkabılarındaki tozu temizlemek için kullanılabilir [45].

Tüm önlem prosesleri arasındaki en yaygın yaklaşım ise doğal olarak güvenli süreç tasarımıdır. Çoğu zaman, mevcut bir sürece önleyici ve hafifletici önlemler ekleyerek toz patlaması tehlikesiyle mücadele etmeye çalışır. Ancak, alınan teknik önlemler genellikle pahalıdır ve güvenlik prosedürleri başarısız olabilir. Doğal güvenlik, sürecin kendisinin hiçbir patlama tehlikesi olmayacak şekilde tasarlanmasını ima eden alternatif bir yaklaşımdır. Doğal olarak güvenli süreç tasarımı konseptinin 'babası' olan Kletz (1999), temel felsefesini özetledi ve mümkün olduğunda kullanılmasını tavsiye etti. Toz patlamalarını önleme ve hafifletme bağlamında, doğası gereği güvenli proses tasarımı, toz bulutu oluşumunun minimumda tutulduğu üretim, arıtma, nakliye ve depolama operasyonlarının kullanımını içerebilir.

Eİ yöntemlerinde patlama önlemlerinin alınmasına yönelik birçok madde belirtilmiş olsa da, toz oluşumu nedeniyle patlama tehlikesi oluştursa da, üç boyutlu yazıcıların Patlamadan Korunma Yönetmeliği'ne göre sertifikalandırılmasına gerek yoktur. Çünkü 2006/42/EC AB Makine Direktifi tanımına göre üç boyutlu yazıcı bir makinedir. ATEX Direktifine (2014/34/EU) ek olarak, genel hükümlerinde (Madde 1 - Kapsam) uygulama aralığını "potansiyel olarak patlayıcı ortamlarda kullanılması amaçlanan ekipman ve koruyucu sistemler" olarak tanımlar. Bu nedenle makine, bir "ekipman" olarak bir patlama alanına yerleştirilmeyeceği için herhangi bir patlama koruma standardına uymak zorunda değildir [46].

\section{SONUÇLAR}

Birçok EI teknolojisinde metal tozları kullanılmaktadır. Bu tozlar yanlış kullanılırsa toz bulutları oluşturarak olası yangınlara ve hatta patlamalara neden olabilir. Uygun işleme prosedürleri çok önemlidir. Prototiplerin yaratılması ve yüksek değerli parça ve bileşenlerin küçük hacimli üretimi için endüstri tarafindan zaten iyi bir şekilde benimsenen Eİ, büyük ölçekli üretim operasyonlarında kullanılmak üzere hızla gelişmektedir. Diğer gelişmiş ve gelişmekte olan akıllı endüstriyel teknolojilerin uygulanmasıyla birlikte Eİ, üretim maliyetlerini düşürürken, pazara sunma süresini iyileştirme, kaynak korumasını artırma ve üretim kalitesini iyileştirme potansiyeline sahiptir. Uzun vadeli başarısı için, Eİ teknolojilerinin daha geniş çapta benimsenmesi, büyük ölçüde bu teknolojilerin benzersiz sağlık ve güvenlik sorunlarının ele alınmasına bağlıdır. Endüstri ve standart geliştirme kuruluşlarının işbirlikçi çabaları, gelecekte yeni ve ortaya çıkan EI güvenliği sorunlarını ele almak için uygun güvenlik yönergelerinin ve standartlarının sürekli olarak geliştirilmesini ve evrimini sağlamaya yardımcı olmak için çok önemlidir.

Endüstriyel tesislerde hâkim olan toz patlama riskleri, basınç ve sıcaklık gibi proses parametrelerinin yanı sıra hareketli elemanların varlığı, bu tür toz işleme ekipmanlarının mekanik mukavemeti, havalandırma, temizlik ve koruyucu önlemler dahil olmak üzere çok çeşitli faktörlere bağlıdır. Bu nedenle, büyük ölçekli testler, patlama 
izolasyon sistemlerini doğrulamak ve ayrıca metal tozlarını işleyen süreçler gibi özel uygulamalar için tasarımları doğrulamak için gereklidir.

Reaktif metal tozu patlamaları için önleme tekniklerinin ve azaltma çözümlerinin geliştirilmesinin zor olduğu tarıışmasızdır. Toz bulutu yanma dinamikleri üzerine mevcut literatür, boyut, polidispersite ve karışım bileşiminin önemini belirtmiş ancak malzeme işlemenin doğasının bağımsız etkilerinin incelenmesine yönelik araştırmalar yeterli seviye değildir.

İkincil patlamalara engel olmak toz patlaması tehlikesiyle mücadeleye yönelik tüm çabalarda en önemli sorun olmaya devam etmektedir. Yeterli temizlik, bu amaca ulaşmanın önemli bir yoludur. Bununla birlikte, gereken temizlik düzeyine ilişkin yanıtlanması gereken sorular hala vardır. Çeşitli koşullar altında ikincil toz alev yayılmasını önlemek için yüzeyin birim alanı başına maksimum kabul edilebilir biriken toz kütlesinin değerlendirilmesi için daha fazla araştırmaya ihtiyaç vardır.

\section{KAYNAKLAR}

[1] Ergür HS (2012) Makine Endüstrisinde Karşılaşılan Toz Patlaması Olayı ve Atex Yönergeleri. Journal of Engineering and Architecture Faculty of Eskişehir Osmangazi University 25(2):1-18.

[2] Kipdaş Mühendislik Çevre ve İş Sağlığı ve Güvenliği Laboratuvar Hizmetleri, Solunabilir toz ölçüm sistemleri. https://www.kipdasmuhendislik.com/is-hijyeni-olcum-test-ve-analiz-laboratuvari/25-solunabilir-tozolcumu-toz-tayini.html\#. Erişim 1 Mart 2021

[3] Grossel SS (1989) Electrostatic hazards in powder handling. J Loss Prev Process Ind 2nd edn. John WileySons, Chichester, UK. pp 171. https://doi.org/10.1016/0950-4230(89)87014-7

[4] Eckhoff RK (2003) Dust Explosions—Origin, Propagation, Prevention, and Mitigation. Dust Explosions in the Process Industries 3rd edn. Gulf Professional Publishing, Houston, Texas, US. pp 1-156. https://doi.org/10.1016/b978-075067602-1/50002-0

[5] Eckhoff RK, Li G (2021) Industrial Dust Explosions. A Brief Review. Appl Sci. https://doi.org/10.3390/app11041669

[6] Sezer P (2019) Alüminyum Toz Patlamalarının İncelenmesi ve Reaktif-Proaktif Önlem Çalışmaları. Dissertation, Gedik Üniversitesi Sağlık Bilimleri Enstitüsü İş Sağlı̆̆ Ve Güvenliği Anabilim Dalı, İstanbul, Türkiye

[7] NFPA 484 Standard for Combustible Metals, National Fire Protection Association, Quincy (2015). MA

[8] Ibarreta AF, Myers TJ (2017) Mitigating fire and explosion hazards of powdered metals. Met Powder Rep 72(1):57-61. https://doi.org/10.1016/j.mprp.2016.01.073

[9] U.S. Chemical Safety and Hazard Investigation Board (2010). Case Study No. 2011-3-I-WV; AL Solutions, Inc., New Cumberland, WV 
[10] Reding NS, Shiflett MB (2018) Metal Dust Explosion Hazards: A Technical Review. Ind Eng Chem Res 57(34):11473-11482. https://doi.org/10.1021/acs.iecr.8b02465

[11] Li G, Yang HX, Yuan CM, Eckhoff RK (2016) A catastrophic aluminium-alloy dust explosion in China. J Loss Prev Process Ind 39:121-130. https://doi.org/10.1016/j.jlp.2015.11.013

[12] Eckhoff RK (2009) Understanding dust explosions. The role of powder science and technology. J Loss Prev Process Ind 22(1):105-116. https://doi.org/10.1016/j.jlp.2008.07.006

[13] Vijayaraghavan G(2004) Impact assessment, modelling, and control of dust explosions in chemical process industries. Dissertation, Department of Chemical Engineering, Coimbatore Institute of Technology, India

[14] Abbasi T, Abbasi SA (2007) Dust explosions-Cases, causes, consequences, and control. J Hazard Mater 140(1-2):7-44. https://doi.org/10.1016/j.jhazmat.2006.11.007

[15] Dust explosion and ignition testing, January. https://www.explosiontesting.co.uk/explosion_ind_10.html. Erişim 1 Mart 2021

[16] Benson JM (2012) Safety considerations when handling metal powders. The Journal of The Southern African Institute of Mining and Metallurgy 7A:563-575.

[17] Eckhoff RK (2009) Understanding dust explosions. The role of powder science and technology. J Loss Prev Process Ind 22(1):105-116. https://doi.org/10.1016/j.jlp.2008.07.006

[18] Dobashi R (2009) Risk of dust explosions of combustible nanomaterials. J Phys Conf Ser. https://doi.org/10.1088/1742-6596/170/1/012029

[19] Dufaud O, Traoré M, Perrin L, Chazelet S, Thomas D (2010) Experimental investigation and modelling of aluminum dusts explosions in the $20 \mathrm{~L}$ sphere. $\mathrm{J}$ Loss Prev Process Ind 23(2):226-236. https://doi.org/10.1016/j.jlp.2009.07.019

[20] Dastidar AG. Nalda-Reyes B, Dahn CJ (2005) Evaluation of dust and hybrid mixture explosion potential in process plants. Process Saf Prog 24(4):294-298. https://doi.org/10.1002/prs.10097

[21] Bagaria P, Prasad S, Sun J, Bellair R, Mashuga C. Effect of particle morphology on dust minimum ignition energy. Powder Technol 355:1-6. https://doi.org/10.1016/j.powtec.2019.07.020

[22] Dust Explosion Fundamentals: Ignition Criteria and Pressure Development Robert Zalosh Firexplo Wellesley, MA 02481. http://dataspan.com/wp-content/uploads/2017/12/Dust-Explosion-White-Paper.pdf. Erişim 1 Mart 2021

[23] Nifuku M, Katoh H. (2003) A study on the static electrification of powders during pneumatic transportation and the ignition of dust cloud. Powder Technol. https://doi.org/10.1016/S0032-5910(03)00163-3 
[24] Combustible Dust Fire and Explosions (2005). Investigation Report for CTA Acoustics, Inc., Washington, DC

[25] Yuan Z, Khakzad N, Khan F, Amyotte P (2016) Domino effect analysis of dust explosions using Bayesian networks. Process Safety and Environmental Protection 100:108-116. https://doi.org/10.1016/j.psep.2016.01.005

[26] Abdolhamidzadeh B, Abbasi T, Rashtchian D, Abbasi SA (2011) Domino effect in process-industry accidents - An inventory of past events and identification of some patterns. J J Loss Prevent Process Ind 24(5):575593. https://doi.org/10.1016/j.jlp.2010.06.013

[27] Cao W, Qin Q, Cao W, Lan Y, Chen T, Xu S, Cao X (2017) Experimental and numerical studies on the explosion severities of coal dust/air mixtures in a 20-L spherical vessel. Powder Technol 310:17-23. https://doi.org/10.1016/j.powtec.2017.01.019

[28] Nozar M, Pokorna V, Zetkova I (2019) Health Hazards of Additive Manufacturing, 30th Daaam International Symposium on Intelligent Manufacturing and Automation. https://doi.org/10.2507/30th.daaam.proceedings.090

[29] Roth GA, Geraci CL, Stefaniak A, Murashov V, Howard J (2019) Potential occupational hazards of additive manufacturing. J Occup Environ Hyg 16(5):321-328. https://doi.org/10.1080/15459624.2019.1591627

[30] Occupational Safety and Health Administration (2014). Hazard Alert: Combustible Dust Explosions, OSHA Fact Sheet, Washington, DC

[31] Yampolskiy M, Schutzle L, Vaidya U, Yasinsac A (2015) Security Challenges of Additive Manufacturing with Metals and Alloys. Int J Crit Infrastruct Prot 9:169-183. https://doi.org/10.1007/978-3-319-26567-4_11

[32] Cashdollar KL, Zlochower IA, Loss Prevent. J Proc Ind 20:337-348

[33] Cheremisinoff NP (2014) Dust Explosion and Fire Prevention Handbook: A Guide to Good Industry Practices, Scrivener Publishing LLC/John Wiley \& Sons, Salem, MA/Hoboken, NJ

[34] NFPA 68 Standard on Explosion Protection by Deflagration Venting (2007). National Fire Protection Association, Quincy, MA

[35] NFPA 484 Standard for Combustible Metals, National Fire Protection Association, Quincy, MA, 2015 Edition.

[36] Villamil C, Nylander J, Hallstedt SI, Schulte J, Watz M (2018) Additive Manufacturing From A Strategic Sustainability Perspective. International Design Conference. https://doi.org/10.21278/idc.2018.0353

[37] Mittal M (2014) Explosion characteristics of micron- and nano-size magnesium powders. J Loss Prev Process Ind 27:55-64. https://doi.org/10.1016/j.jlp.2013.11.001

[38] Reding NS, Farrell TM, Verma A, Shiflett MB (2021) Effect of particle morphology on metal dust deflagration sensitivity and severity. J Loss Prev Process Ind. https://doi.org/10.1016/j.jlp.2021.104396

[39] Tascón A (2018) Influence of particle size distribution skewness on dust explosibility. Powder Technology 338:438-445. https://doi.org/10.1016/j.powtec.2018.07.044 
[40] Popov VV, Grilli ML, Koptyug A, Jaworska L, Katz-Demyanetz A, Klob`car D, Balos S, Postolnyi BO, Goel S (2021) Powder Bed Fusion Additive Manufacturing Using Critical Raw Materials: A Review. Materials. https://doi.org/10.3390/ma14040909

[41] Thistle J, Amyottea P, Ripleya R, Hossaina N (2014) Current Status of Nanopowder Dust Explosion Research: A Critical Review. 17th Annual International Symposium, Texas, USA Oct. 28-30.

[42] Davis SG, Hinze PC, Hansen OR, Wingerden K (2011) Does your facility have a dust problem: Methods for evaluating dust explosion hazard. J Loss Prev Process Ind 24(6):837-846. https://doi.org/10.1016/j.jlp.2011.06.010

[43] Ebadat V (2010) Dust explosion hazard assessment. J Loss Prev Process Ind 23(6):907-912. https://doi.org/10.1016/j.jlp.2010.05.006

[44] Faq: How Long Do Conductive and Static-Dissipative Properties Last in ESD Flooring? (2021). https://kb.staticworx.com/faq/duration-conductive-static-dissipative-properties-esd-flooring/. Erişim 1 Mart 2021.

[45] Scime L, Wolf SD, Beuth J, Mrdjenovich S, M. Kelley M (2018) Safety and Workflow Considerations for Modern Metal Additive Manufacturing Facilities. JOM 70(9):1830-1834. https://doi.org/10.1007/s11837-0182971-4

[46] Explosion Protection Safety Assessment for 3D printers. https://www.tuv.com/content-mediafiles/master-content/services/industrial-services/1164-tuv-rheinland-explosion-protection-testing-andcertification/tuv-rheinland-whitepaper-3d-printers-en.pdf. Erişim 1 Mart 2021 